\title{
Prevalensi dan Pola Sensitivitas Antimikrob Multidrug Resistant Pseudomonas aeruginosa di RSUD Arifin Achmad
}

\author{
Dewi Anggraini, ${ }^{1}$ Utari Gusti Yulindra, ${ }^{2}$ Maya Savira, ${ }^{1}$ Fauzia Andrini Djojosugito, ${ }^{1}$ Nopian Hidayat ${ }^{3}$ \\ ${ }^{1}$ Bagian Mikrobiologi, Fakultas Kedokteran Universitas Riau/RSUD Arifin Achmad Pekanbaru, Indonesia, \\ ${ }^{2}$ Fakultas Kedokteran Universitas Riau Pekanbaru, Indonesia, ${ }^{3}$ Bagian Anestesi dan Terapi Intensif \\ Fakultas Kedokteran Universitas Riau/RSUD Arifin Achmad Pekanbaru, Indonesia
}

\begin{abstract}
Abstrak
Resistensi antimikrob merupakan salah satu masalah kesehatan masyarakat yang besar yang dihadapi manusia sejak era ditemukan antimikrob. Angka multidrug resistant $P$. aeruginosa salah satunya semakin meningkat di berbagai belahan dunia yang berdampak pada kesulitan penanganan infeksi oleh bakteri ini. Penelitian deskriptif retrospektif ini bertujuan mengetahui prevalensi MDR P.aeruginosa dan pola sensitivitasnya. Data diambil dari hasil kultur bakteri dan uji resistensi antibiotik dari berbagai spesimen klinis pasien di RSUD Arifin Achmad sepanjang tahun 2015. Uji resistensi dilakukan dengan menggunakan alat Vitek 2 compact. MDR $P$. aeruginosa didefinisikan sebagai $P$. aeruginosa yang tidak sensitif terhadap tiga atau lebih golongan antibiotik berikut: meropenem atau imipenem, siprofloksasin, gentamisin atau amikasin, seftazidim atau sefepim, dan piperasilin/ tazobaktam. Prevalensi MDR P. aeruginosa adalah 45,5\%. Isolat MDR P. aeruginosa serta paling banyak berasal dari instalasi perawatan surgikal dan instalasi perawatan intensif, dan paling banyak berasal dari spesimen pus dan sputum. Sensitivitas P. aeruginosa paling baik dengan amikasin (76,9\%), piperasilin/tazobaktam $(57,2 \%)$, meropenem $(57,0 \%)$, gentamisin (54,5\%), sefepim (53,7\%), seftazidim (49,6\%), ciprofloksasin $(48,8 \%)$ dan aztreonam (35,5\%). Sensitivitas MDR P.aeruginosa terhadap antibiotik jauh lebih rendah dibanding dengan $P$. aeruginosa. Penelitian ini menunjukkan angka MDR P. aeruginosa tinggi khususnya di Pekanbaru. Pola sensitifas P. aeruginosa dapat menjadi pedoman dalam memilih antibiotik yang sesuai untuk infeksi karena P. aeruginosa.
\end{abstract}

Kata kunci: Multidrug resistant, Pekanbaru, pseudomonas aeruginosa, sensitivitas antibiotik

\section{Prevalence and Antimicrobial Susceptibility Profile of Multidrug Resistant Pseudomonas aeruginosa in Arifin Achmad General Hospital}

\begin{abstract}
Antimicrobial resistance is one of major public health problems since the era of antimicrobial discovery, inclusing multidrug resistant (MDR) P. aeruginosa. The prevalence of this resistance is increasing in different parts of the world, leading to the difficulties in dealing with this bacteria. The aim of this descriptive retrospective study was to determine the prevalence of MDR P. aeruginosa and its susceptibility profile. Data were collected from the bacteria cultures and antibiotic susceptibility test results from various clinical specimens in Arifin Achmad General Hospital throughout 2015. The test was performed in VITEK 2 Compact. MDR P. aeruginosa is defined as P. aeruginosa which is not sensitive to three or more following antibiotics: meropenem or imipenem, ciprofloxacin, gentamicin or amikacin, ceftazidime or cefepime, and piperacilin/tazobactam. The prevalence of MDR P. aeruginosa was $45.5 \%$. The isolates of MDR P. aeruginosa was mostly derived from pus and sputum specimens from the surgical ward and intensive care unit. The most sensitive antibiotics was amikacin (76.9\%) followed by piperacilin/tazobactam (57.2\%), meropenem (57.0\%), gentamicin (54.5\%), cefepime (53.7\%), ceftazidime (49.6\%), ciprofloxacin (48.8\%), and aztreonam (35.5\%). Antibiotic sensitivity in MDR P. aeruginosa was much lower than in P. aeruginosa. This study shows a high prevalence of MDR P. aeruginosa, especially in Pekanbaru. This susceptibility profile can serve as a guideline for the selection of appropriate antibiotics for infections caused by P. aeruginosa.
\end{abstract}

Key words: Antibiotic susceptibility, multidrug resistant, Pekanbaru, pseudomonas aeruginosa

Korespondensi: Dewi Anggraini, dr., SpMK, Bagian Mikrobiologi, Fakultas Kedokteran Universitas Riau/RSUD Arifin Achmad Pekanbaru, Jalan Diponegoro No.1, Suka Mulia, Sail, Kota Pekanbaru, Riau 28133, E-mail: dewianggarainiyovi@gmail.com 


\section{Pendahuluan}

Pseudomonas aeruginosa merupakan bakteri Gram negatif aerob yang bersifat nonfermenter. Bakteri ini banyak sekali ditemukan di berbagai lingkungan seperti tanah, bahan organik, air, tumbuhan, hewan, permukaan yang lembap, termasuk lingkungan rumah sakit dan peralatan kesehatan. ${ }^{1}$ Bakteri ini menyebabkan infeksi terutama pada orang dengan imunokompromais dan juga termasuk tiga besar penyebab infeksi oportunistik terhadap manusia. $P$. aeruginosa merupakan patogen utama pada infeksi yang didapatkan di rumah sakit. Bakteri ini dapat menyebabkan infeksi seperti pneumonia, infeksi saluran kemih, infeksi gastrointestinal, sepsis, osteomielitis, peritonitis, infeksi jaringan lunak, infeksi kulit termasuk infeksi pada luka dan luka bakar. $^{2}$

Resistensi antimikrob merupakan salah satu masalah kesehatan masyarakat yang dihadapi manusia sejak era ditemukan antimikrob. ${ }^{3} P$. aeruginosa merupakan salah satu bakteri yang memiliki semua mekanisme resistensi yang diketahui. ${ }^{3}$ Multidrug resistant $P$. aeruginosa (MDR $P$. aeruginosa) adalah $P$. aeruginosa yang resisten dengan tiga atau lebih golongan antibiotik pilihan untuk bakteri ini.. ${ }^{4}$ Angka MDR $P$. aeruginosa yang meningkat di berbagai belahan dunia, yang berdampak pada sulitnya penanganan infeksi oleh bakteri ini. Infeksi oleh MDR $P$. aeruginosa meningkatkan angka kematian, lama rawat, dan biaya rumah sakit. Angka resistensi ini sangat bervariasi secara geografis, dilaporkan rendah di beberapa negara, namun sangat tinggi di beberapa negara lain. ${ }^{3}$ Laporan angka resistensi $P$. aeruginosa termasuk prevalensi multidrug resistant $P$. aeruginosa (MDR P.a eruginosa), di Indonesia khususnya di Pekanbaru sangat terbatas.

\section{Metode}

Penelitian ini merupakan penelitian retrospektif yang dilakukan dari Januari sampai Oktober 2016. Data diambil dari hasil pemeriksaan kultur dan uji resistensi yang dikerjakan di Bagian Mikrobiologi Laboratorium Patologi Klinik RSUD Arifin Achmad. Populasi adalah seluruh data hasil kultur bakteri dan uji resistensi antibiotik dari berbagai spesimen klinik pasien di RSUD Arifin Achmad periode 1 Januari-31 Desember 2015. Sampel adalah hasil kultur dan uji resistensi antibiotik P. aeruginosa, dengan kriteria eksklusi, yaitu data yang tidak lengkap yang meliputi jenis bakteri, hasil uji resistensi antibiotik, asal ruangan, dan jenis spesimen.

Prosedur pemeriksaan di Bagian Mikrobiologi Laboratorium Patologi Klinik RSUD Arifin Achmad dimulai dengan penanaman spesimen klinik di medium yang sesuai dengan inkubasi di lingkungan yang sesuai, untuk mendapatkan $P$. aeruginosa spesimen ditanam di medium agar darah dan McConkey, dan diinkubasi pada incubator anaerob dalam waktu 18 jam. Koloni tersangka $P$. aeruginosa dinilai dari morfologi koloni dan pewarnaan Gram, dan dilanjutkan dengan identifikasi menggunakan alat VITEK 2 compact. Uji resistensi antibiotik $P$. aeruginosa juga dilakukan dengan alat VITEK 2 Compact. Jenis antibiotik yang diujikan adalah ampisilin, ampisilin/sulbaktam, piperasilin/tazobaktam, sefazolin, seftriakson, seftazidim, sefepim, aztreonam, meropenem, ertapenem, gentamisin, amikasin, tigesiklin, siprofloksasin, trimetroprim/sulfametoksazol, dan nitrofurantoin. MDR P. aeruginosa adalah $P$. aeruginosa yang tidak sensitif dengan tiga atau lebih golongan antibiotik berikut: meropenem/ imipenem, siprofloksasin, gentamisin atau amikasin, seftazidim atau sefepim, dan juga piperasilin/tazobaktam. ${ }^{4}$

Pengumpulan data pemeriksaan kultur dan uji resistensi didapat dari buku register. Hasil kultur bakteri serta uji resistensi antibiotik dicetak dari alat VITEK 2 compact sesuai dengan yang tertera dalam buku registrasi, kemudian dilakukan pemeriksaan kembali kelengkapan data. Data-data dan hasil uji resistensi antibiotik, asal ruangan, dan jenis spesimen dimasukkan ke dalam perangkat lunak WHONET 5.6. Pengolahan data termasuk pola sensitivitas antimikrob dilakukan dengan WHONET 5.6. Untuk menilai perbedaan hasil identifikasi bakteri berdasar atas lokasi dan asal spesimen digunakan uji statistik koefisien kontingensi. Penelitian ini telah lolos kaji etik dari Unit Etika Penelitian Fakultas Kedokteran dan Kesehatan Fakultas Kedokteran Universitas Riau dengan nomor 190/UN.19.5.1.1.8/UEPKK/2016.

\section{Hasil}

Sepanjang tahun 2015 diisolasi 1.121 bakteri dengan jumlah isolat $P$. aeruginosa adalah 121, dan menempati urutan ketiga organisme tersering diisolasi. MDR P. aeruginosa didapatkan pada 55 dari 121 isolat $P$. aeruginosa $(45,5 \%)$. Pada penelitian ini juga didapatkan $P$. aeruginosa yang resisten dengan semua antibiotik yang 
Tabel 1 Distribusi MDR P. aeruginosa dan non MDR P.aeruginosa berdasar atas Asal Ruangan

\begin{tabular}{lccc}
\hline Ruangan & MDR P. aeruginosa & $\begin{array}{c}\text { Non MDR } \\
\text { P. aeruginosa }\end{array}$ & Total \\
\hline Instalasi Perawatan Intensif dewasa & 8 & 10 & 18 \\
Instalasi Perawatan Neonatus & 0 & 4 & 4 \\
Instalasi Perawatan Intensif Anak & 7 & 9 & 16 \\
IRNA Medikal & 5 & 13 & 18 \\
IRNA Surgikal & 29 & 18 & 47 \\
VIP & 2 & 8 & 10 \\
Instalasi Fetomaternal & 0 & 1 & 1 \\
Poliklinik & 4 & 3 & 121 \\
Total & 55 & 66 & 7 \\
\hline
\end{tabular}

Keterangan: $p=0,111$

diujikan merupakan antibiotik pilihan untuk $P$. aeruginosa, yaitu sebanyak 8 dari 121 isolat $(6,6 \%)$.

Distribusi MDR dan non MDR $P$. aeruginosa asal ruangan dapat dilihat pada Tabel 1. MDR $P$. aeruginosa lebih sering ditemukan di IRNA Surgikal dan poliklinik dibanding dengan non MDR P.aeruginosa, sedangkan di ruangan lain non MDR P. aeruginosa lebih sering ditemukan. MDR $P$. aeruginosa paling tinggi prevalensinya di IRNA surgikal (62\%). Isolat MDR P. aeruginosa paling banyak berasal dari IRNA Surgikal (52,7\%) dan Instalasi Perawatan Intensif dewasa dan anak (14,5\% dan 12,7\% masing-masing). Berdasar atas uji statistik tidak ada perbedaan bermakna proporsi MDR $P$. aeruginosa dan non MDR $P$. aeruginosa berdasarkan asal ruangan $(\mathrm{p}>0,05)$.

Distribusi MDR dan non MDR P. aeruginosa asal spesimen dapat dilihat pada Tabel 2. MDR $P$. aeruginosa lebih sering ditemukan dalam urin dibanding dengan non MDR Paeruginosa, sedangkan pada spesimen lain non MDR $P$. aeruginosa lebih sering ditemukan. MDR $P$. aeruginosa paling tinggi prevalensinya pada isolat $P$. aeruginosa yang berasal dari spesimen urin, darah, dan pus. Isolat MDR P. aeruginosa paling banyak berasal dari spesimen pus $(70,2 \%)$ dan sputum (32,7\%). Berdasarkan uji statistik tidak ada perbedaan bermakna proporsi MDR $P$. aeruginosa dan non MDR $P$. aeruginosa berdasarkan asal spesimen ( $p>0,05)$.

Pola sensitivitas antimikrob $P$. aeruginosa dan MDR P. aeruginosa dapat dilihat pada Tabel 3. Sensitivitas $P$. aeruginosa paling baik dengan amikasin (76,9\%), piperasilin/tazobaktam $(57,2 \%)$, meropenem $(57,0 \%)$, gentamisin $(54,5 \%)$, sefepim $(53,7 \%)$, seftazidim $(49,6 \%)$, siprofloksasin $(48,8 \%)$ dan aztreonam $(35,5 \%)$. Sensitititas $P$. aeruginosa dengan antibiotik lain sangat rendah yaitu kurang dari $10 \%$.

Kepekaan bakteri MDR P. aeruginosa terhadap antibiotik jauh lebih rendah dibanding dengan

Tabel 2 Distribusi MDR P.aeruginosa dan non MDR P.aeruginosa berdasar atas Jenis Spesimen

\begin{tabular}{lccc}
\hline \multicolumn{1}{c}{ Jenis Spesimen } & MDR P. aeruginosa & Non MDR P. aeruginosa & Total \\
\hline Pus & 33 & 37 & 70 \\
Darah & 2 & 2 & 4 \\
Sputum & 18 & 25 & 43 \\
Urin & 2 & 0 & 2 \\
Dll & 0 & 2 & 2 \\
Total & 55 & 66 & 121 \\
\hline
\end{tabular}

Keterangan: $p=0,354$ 
Tabel 3. Pola Sensitifitas Antimikoba Paeruginosa

\begin{tabular}{|c|c|c|}
\hline Antibiotik & P. aeruginosa $(\mathrm{n}=121)$ & MDR P.aeruginosa $(\mathrm{n}=55)$ \\
\hline Ampisilin & $0,8 \%$ & $0 \%$ \\
\hline Ampisilin/Sulbaktam & $5,8 \%$ & $3,63 \%$ \\
\hline Piperasilin/Tazobaktam & $57,2 \%$ & $20,0 \%$ \\
\hline Sefazolin & $0,8 \%$ & $0 \%$ \\
\hline Seftriakson & $1,7 \%$ & $0 \%$ \\
\hline Seftazidim & $49,6 \%$ & $10,9 \%$ \\
\hline Sefepim & $53,7 \%$ & $18,2 \%$ \\
\hline Aztreonam & $35,5 \%$ & $14,5 \%$ \\
\hline Meropenem & $57,0 \%$ & $25,5 \%$ \\
\hline Gentamisin & $54,5 \%$ & $16,4 \%$ \\
\hline Amikasin & $76,9 \%$ & $50,9 \%$ \\
\hline Siprofloksasin & $48,8 \%$ & $9,1 \%$ \\
\hline Tigesiklin & $8,5 \%$ & $5,5 \%$ \\
\hline Trimetroprim/Sulfametoksazol & $4,1 \%$ & $3,6 \%$ \\
\hline Nitrofurantoin & $0,8 \%$ & $0 \%$ \\
\hline
\end{tabular}

P. aeruginosa (Tabel 3). Sensitivitas MDR $P$. aeruginosa paling baik dengan amikasin, namun persentasenya hanya $50,9 \%$. Antibiotik lain yang merupakan pilihan terapi untuk $P$. aeruginosa seperti meropenem, piperasilin/tazobaktam, sefepim, gentamisin, aztreonam, seftazidim dan siprofloksasin berturut-turut 25,5\%, 20,0\%, $18,2 \%, 16,4 \%, 14,5 \%, 10,9 \%$ dan $9,1 \%$.

\section{Pembahasan}

P. aeruginosa memiliki sifat resisten secara instrinsik terhadap banyak antibiotik, bakteri ini juga dapat memperoleh sifat resisten terhadap antibiotik lain selama terapi. Sifatsifat ini membuat pilihan antibiotik untuk $P$. aeruginosa menjadi terbatas. ${ }^{5}$ Pada penelitian ini didapatkan prevalensi MDR P. aeruginosa adalah 45,5\%. Prevalensi MDR P. aeruginosa bervariasi bergantung pada letak geografis dan juga jenis penelitian surveilans yang dilakukan, angkanya berkisar 0,6-32\%. Review lain telah melaporkan angka MDR $P$. aeruginosa bervariasi dari nilai yang rendah $1-6 \%$, sampai $70 \%{ }^{6}$

Penelitian di Padang mendapatkan angka MDR $P$. aeruginosa adalah $34,17 \%$. $^{7}$ Surveilans nasional di Thailand pada tahun 2000-2005 mendapatkan angka MDR P. aeruginosa berkisar $20-30 \%$, sedangkan di suatu rumah sakit tersier di Bangkok mendapatkan 43,22\%.8,9 Hasil metaanalisis di Cina, sampai tahun 2014 didapatkan angka MDR $P$. aeruginosa pada infeksi rumah sakit adalah $29,0 \%$ dan angka ini meningkat secara bermakna dari tahun ke tahun. ${ }^{10}$ Angka carbapenem resistant $P$. aeruginosa di Taiwan tahun 2000-2005 relatif rendah yaitu 10,2\%, demikian juga hasil penelitian di Fukuoko Jepang angka MDR P. aeruginosa, yaitu 3,3\% di tahun 2006-2008. ${ }^{11,12}$

Penelitian di sepuluh negara di benua Eropa tahun 1997-2000, melaporkan angka MDR $P$. aeruginosa adalah $12,2 \%$, angka ini bervariasi dari 50\% di Turki, 25\% di Italia, 14\% di Belgia sampai dengan 3\% di Spanyol, Inggris, Jerman, Bulgaria, dan Malta. Prevalensi MDR P. aeruginosa di Amerika Serikat tahun 2000-2009 pada pasien anak yang dirawat dengan sepsis dan pneumonia masing-masing berkisar 10,7-13,5\% dan 19,2-21,7\%. ${ }^{13}$ Prevalensi MDR P. aeruginosa di Brazil tahun 2010-2012 adalah 37\%.14

Pada penelitian ini tidak ada perbedaan bermakna proporsi MDR $P$. aeruginosa dengan non MDR $P$. aeruginosa berdasar atas asal ruangan. Multidrug resistant $P$. aeruginosa yang paling banyak berasal dari IRNA surgikal dan Instalasi Perawatan Intensif dewasa dan anak. Faktor risiko yang berhubungan dengan kejadian MDR $P$. aeruginosa adalah pasien intensive care unit (ICU), menjalani pembedahan dan memakai 
alat-alat invasif. Beberapa penelitian melaporkan pevalensi MDR P. aeruginosa secara bermakna lebih tinggi pada pasien ICU dibanding dengan pasien non ICU, laporan lain juga menunjukkan kejadian luar biasa oleh MDR $P$. aeruginosa di ICU ${ }^{5,10,14}$

Tidak ada perbedaan bermakna proporsi MDR P. aeruginosa dengan non MDR P. aeruginosa berdasar atas asal spesimen pada penelitian ini, isolat MDR $P$. aeruginosa paling banyak berasal dari spesimen pus dan sputum. Hasil ini hampir sama dengan penelitian di Padang, MDR $P$. aeruginosa paling sering ditemukan dalam sputum dan pus. ${ }^{7}$ National Antimicrobial Resistance Surveillance, Thailand (NARST) telah mendapatkan $P$. aeruginosa paling sering ditemukan di sputum, pus dan urin. ${ }^{8}$ Penelitian di Pakistan juga mendapatkan MDR P. aeruginosa paling sering ditemukan di pus, luka, urin, darah, dan sputum. ${ }^{16} P$. aeruginosa merupakan penyebab tersering pneumonia rumah sakit, penyebab ketiga tersering dari infeksi saluran kemih, penyebab keempat tersering dari infeksi daerah operasi dan patogen ketujuh tersering yang diisolasi dari darah. ${ }^{7}$ P. aeruginosa memiliki berbagai mekanisme resistensi antibiotik, seperti produksi enzim beta laktamase AmpC, produksi enzim extended-spectrum betalactamase, modifikasi porin yang spesifik untuk karbapenem, multi-drug efflux pump, dan pembentukan biofilm. ${ }^{3}$

Sensitivitas P. aeruginosa pada penelitian ini paling baik dengan amikasin (76,9\%). Amikasin merupakan antibiotik golongan aminoglikosida. Sensitivitas $P$. aeruginosa dengan golongan aminoglikosida lain, yaitu gentamisin adalah 54,5\%. Aminoglikosida antipseudomonal merupakan komponen penting dalam kemoterapi antipseudomonal. Antibiotik golongan ini bersifat bakterisidal dan juga memperlihatkan sinergi dengan antipseudomonal lain terutama beta laktam. Resistensi terhadap aminoglikosida sangat bervariasi di seluruh dunia, bervariasi dari kurang dari $25 \%$ sampai lebih dari $50 \%$. Angka resistensi terhadap tobramisin dan amikasin dilaporkan di beberapa penelitian berkisar 2-50\%. ${ }^{3}$ Penelitian di Padang juga melaporkan sensitivitas $P$. aeruginosa terhadap amikasin juga paling baik $(91,14 \%)$, sedangkan dengan gentamisin $67,09 \% .{ }^{7}$ Hal yang sama juga didapatkan pada penelitian di Brazil, sensitivitas P. aeruginosa yang didapatkan dari ICU terhadap amikasin juga paling baik $(85,2 \%)$, sedangkan dengan gentamisin $53,7 \%{ }^{14}$ Sensitivitas $P$. aeruginosa di Pakistan terhadap amikasin adalah $46,1 \%$, sedikit lebih rendah dibanding dengan imipenem (56,9\%). ${ }^{16}$ Sensitivitas yang cukup baik terhadap amikasin menunjukkan pemakaian amikasin yang tidak terlalu sering, disebabkan oleh risiko ototoksisitas dan nefrotoksisitas dan harganya yang mahal. ${ }^{3}$

Pada penelitian ini sensitivitas $P$. aeruginosa dengan golongan beta laktam itu berkisar $50 \%$. Sensitivitas terbaik dengan antibiotik piperasilin/tazobaktam $(57,2 \%)$ dan juga diikuti dengan meropenem $(57,0 \%)$, serta sefalosporin generasi keempat, yaitu sefepim $(53,7 \%)$ dan sefalosporin ketiga seftazidim (49,6\%). Sensititas dengan golongan monobaktam aztreonam hanya $35,5 \%$. Antibiotik beta laktam yang memiliki antipseudomonal merupakan komponen utama tata laksana infeksi oleh P.aeruginosa. Penelitian di Padang melaporkan sensitivitas P. aeruginosa terhadap golongan beta laktamase lebih baik, yaitu dengan piperasilin $(84,81 \%)$, tikarsilin (70,89\%), imipenem $(77,22 \%)$, meropenem $(75,95 \%)$, seftazidim $(69,62 \%)$ dan sefoperazon $(59,49 \%){ }^{5}$ P. aeruginosa yang didapatkan dari ICU di Brazil memiliki sensitivitas terhadap golongan beta laktamase lebih rendah yaitu dengan piperasilin/tazobaktanm (53,7\%), tikarsilin $(70,89 \%)$, imipenem dan meropenem berturut-turut 35,2\%, sefepim 51,9\% dan seftazidim (37,0\%). Sensitivitas $P$. aeruginosa di Pakistan terhadap imipenem adalah 43,1\% dan sefoperazon/sulbaktam 50,98\%. ${ }^{14}$ Angka resistensi piperasilin/tazobaktam dilaporkan berbeda di berbagai belahan dunia bervariasi dari 9\% sampai 29\%. ${ }^{3}$ Perbedaan ini disebabkan oleh perbedaan tingkat pemakaian di berbagai wilayah. Pemakaian piperasilin/tazobaktam yang terbatas berhubungan dengan harganya yang mahal. ${ }^{3}$ Resistensi karbapenem pada isolat klinis $P$. aeruginosa meningkat karena pemakaian karbapenem yang sangat luas. Hal ini merupakan tantangan yang sangat berat karena karbapenem merupakan pilihan terakhir terapi antibiotik untuk P.aeruginosa. Laporan dari berbagai negara menunjukkan resistensi terhadap meropenem meningkat, bervariasi kurang dari 10\% sampai 46\%. ${ }^{3}$ Angka resistensi terhadapa seftazidim juga meningkat, bervariasi di berbagai negara antara 10 dan $50 \%$.

Sensitivitas $P$. aeruginosa pada penelitian ini dengan golongan kuinolon, yaitu siprofloksasin adalah 48,8\%. Pemakaian kuionolon untuk infeksi $P$. aeruginosa meningkat sejalan dengan peningkatan resistensi terhadap beta laktam dan aminoglikosida. Kuinolon bersifat bakterisidal dengan sprektrum yang luas dan menunjukkan sinergi memakai antibiotik antipseudomonal golongan lain. Pemakaiannya yang meningkat 
meningkatkan laju resistensi dan angkanya bervariasi di berbagai negara. ${ }^{3}$ Penelitian di Padang melaporkan sensitivitas $P$. aeruginosa terhadap golongan kuinolon lebih baik, yaitu siprofloksasin $69,62 \%$ serta pada levofloksasin $73,42 \%{ }^{5}$ P. aeruginosa yang didapatkan dari ICU di Brazil memiliki sensitivitas terhadap dengan siprofloksasin juga lebih baik 59,3\%. Sensitivitas $P$. aeruginosa dengan antibiotik lain sangat rendah yaitu kurang dari $10 \%$, hal ini disebabkan oleh bakteri ini memiliki sifat yang instrinsik resisten dengan antibiotik-antibiotik tersebut.

Sensitivitas MDR P. aeruginosa pada penelitian ini jauh lebih rendah bila dibanding dengan $P$. aeruginosa secara keseluruhan. Sensitivitas MDR $P$. aeruginosa paling baik dengan amikasin, namun persentasenya hanya $50,9 \%$. Antibiotik lain yang merupakan pilihan terapi untuk $P$. aeruginosa sensitivitasnya di bawah 30\%. Strategi untuk terapi MDR P. aeruginosa meliputi penggunaan antibiotik alternatif, pemberian dosis alternatif, serta kombinasi antibiotik serta antibiotik inhalasi untuk pneumonia. Kolistin sudah menjadi standar terapi infeksi MDR $P$. aeruginosa. Penggunaan antibiotik ini di berbagai negara terbatas karena efek nefrotoksisitasnya. ${ }^{17,18}$ Kolistin ini tidak tersedia di Indonesia. Antibiotik alternatif untuk infeksi oleh MDR P. aeruginosa meliputi seftazidim/ avibaktam dan juga seftolozan/tazobaktam. ${ }^{18}$ Namun, kedua antibiotik inipun belum tersedia di Indonesia. Kombinasi fosfomisin dengan antibiotik lain seperti karbapenem bisa menjadi regimen alternatif. ${ }^{19}$ Fosfomisin intravena merupakan antibiotik lama yang mempunyai aktivitas bakterisidal in vitro yang sangat baik terhadap banyak organism, termasuk $P$. aeruginosa, terutama yang multiresisten. ${ }^{19}$ Beberapa uji klinik melaporkan perbaikan secara klinis dan mikrobiologik pemberian kombinasi fosfomisin dengan antibiotik lain pada infeksi oleh P.aeruginosa. ${ }^{20}$

Penelitian ini menunjukkan angka MDR $P$. aeruginosa khususnya di Pekanbaru, sensitivitas $P$. aeruginosa dapat menjadi pedoman dalam memilih antibiotik yang sesuai untuk infeksi $P$. aeruginosa.

\section{Daftar Pustaka}

1. Lister PD, Wolter DJ, Hanson ND. Antibacterial-resistant Pseudomonas aeruginosa: clinical impact and complex regulation of chromosomally encoded resistance mechanisms. Clin Microbiol Rev. 2009;22(4):582-610.

2. Wu DC, Chan WW, Metelitsa AI, Fiorillo L, Lin AN. Pseudomonas skin infection. Am J Clin Dermatol. 2011;12(3):157-169.

3. El Zowalaty ME, Al Thani AA, Webster TJ, El Zowalaty AE, Schweizer HP, Nasrallah GK, dkk. Pseudomonas aeruginosa: arsenal of resistance mechanisms, decades of changing resistance profiles, and future antimicrobial therapies. Future Microbiol. 2015;10(10):1683-706.

4. Magiorakos AP, Srinivasan A, Carey RB, Carmeli Y, Falagas ME, Giske CG, dkk. Multidrug-resistant, extensively drugresistant and pandrug-resistant bacteria: an international expert proposal for interim standard definitions for acquired resistance. Clin Microbiol Infect. 2012;18(3):268-81.

5. Kanj SS, Kanafani ZA. Current concepts in antimicrobial therapy against resistant gram-negative organisms: extendedspectrum beta-lactamase-producing Enterobacteriaceae, carbapenem-resistant Enterobacteriaceae, and multidrug-resistant Pseudomonas aeruginosa. Mayo Clin Proc. 2011;86(3):250-9.

6. Nathwani D, Raman G, Sulham K, Gavaghan $\mathrm{M}$, Menon V. Clinical and economic consequences of hospital-acquired resistant and multidrug-resistant Pseudomonas aeruginosa infections: a systematic review and meta-analysis. Antimicrob Resist Infect Control. 2014;3(32):1-16.

7. Rustini, Istiqamah $S$, Armin F. Penentuan multidrug resisten Pseudomonas aeruginosa (MDRPA) yang berasal dari sampel klinis pasien RSUP Dr. M. Djamil Padang. Prosiding Rakernas dan Pertemuan Ilmiah Tahunan Ikatan Apoteker Indonesia; 2016 September 26; Yogyakarta. Indonesia. Indonesia: IAI; 2016.

8. Dejsirilert S, Suankratay C, Trakulsomboon S, Thongmali O, Sawanpanyalert P, Aswapokee N, dkk. National Antimicrobial Resistance Surveillance, Thailand (NARST) data among clinical isolates of Pseudomonas aeruginosa in Thailand from 2000 to 2005. J Med Assoc Thai. 2009;92(4):68-75.

9. Katvoravutthichai C, Boonbumrung $\mathrm{K}$, Tiyawisutsri R. Prevalence of $\beta$-lactamase classes A, C, and D among clinical isolates of Pseudomonas aeruginosa from a tertiarylevel hospital in Bangkok, Thailand. Genet Mol Res. 2016;15(3):1-12.

10. Peng Y, Shi J, Bu T, Li Y, Ye X, Chen X, dkk. 
Alarming and increasing prevalence of multidrug-resistant Pseudomonas aeruginosa among healthcare-associated infections in China: a meta-analysis of crosssectional studies. J Glob Antimicrob Resist. 2015;3(3):155-60.

11. Lin KY, Lauderdale TL, Wang JT, Chang SC. Carbapenem-resistant Pseudomonas aeruginosa in Taiwan: prevalence, risk factors, and impact on outcome of infections. J Microbiol Immunol Infect. 2016;49(1):529.

12. Yoshimura $\mathrm{H}$, To $\mathrm{H}$, Narita $\mathrm{C}$, Tokushige $\mathrm{C}$, Kakudo T, Otsubo C, dkk. Antimicrobial susceptibility patterns of Pseudomonas aeruginosa isolated from 2006 to 2008 in Fukuoka University Hospital. Jpn J Antibiot. 2009; 62(6):502-8.

13. Logan LK, Gandra S, Mandal S, Klein EY, Levinson J, Weinstein RA, dkk. Multidrugand carbapenem-resistant Pseudomonas aeruginosa in children, United States, 1999-2012. J Pediatric Infect Dis Soc. 2016;20(20):1-8.

14. de Matos ECO, de Matos HJ, Conceição ML, Rodrigues YC, Carneiro I dan Lima KVB. Clinical and microbiological features of infections caused by Pseudomonas aeruginosa in patients hospitalized in intensive care units. Rev Soc Bras Med Trop. 2016;49(3):305-11.

15. Knoester M, de Boer MG, Maarleveld JJ, Claas EC, Bernards AT, de Jonge E, dkk. Anintegrated approach to control a prolonged outbreak of multidrug-resistant Pseudomonas aeruginosa in an intensive care unit. Clin Microbiol Infect. 2014;20(4):207-15.

16. Ullah W, Qasim M, Rahman H, Bari F, Khan S, Rehman ZU, et al. Multi drug resistant Pseudomonas aeruginosa: pathogen burden and associated antibiogram in a tertiary care hospital of Pakistan. Microb Pathog. 2016;97(1):209-12.

17. Alvarez-Lerma F, Grau S. Management of antimicrobial use in the intensive care unit. Drugs. 2012;72(4):447-70.

18. Cerceo E, Deitelzweig SB, Sherman BM, Amin AN. Multidrug-resistant gram-negative bacterial infections in the hospital setting: overview, implications for clinical practice, and emerging treatment options. Microb Drug Resist. 2016;22(5):412-31.

19. Falagas ME, Kastoris AC, Karageorgopoulos DE, Rafailidis PI. Fosfomycin for the treatment of infections caused by multidrug-resistant non-fermenting Gram negative bacilli: a systematic review of microbiological, animal and clinical studies. Int J Antimicrob Agents. 2009;34(2):111-20.

20. Samonis G, Maraki S, Karageorgopoulos DE, Vouloumanou EK, Falagas ME. Synergy of fosfomycin with carbapenems, colistin, netilmicin, aEnd tigecycline against multidrug-resistant Klebsiella pneumoniae, Escherichia coli, and Pseudomonas aeruginosa clinical isolates. Eur J Clin Microbiol Infect Dis. 2012;31(5):695-701. 